\title{
The Effects of Tubal Sterilization on the Tuba, Ovaries, and Endometrium in a Rat Model
}

\author{
Rat Modelinde Tubal Sterilizasyonun Tuba, Yumurtalıklar ve Endometrium Üzerine Etkileri
}

\author{
Rulin Deniz'1 , Yakup Baykuș ${ }^{1}$, Yasemen Adalı², Muhammet Bora Uzuner ${ }^{3}$, Ömür Öztürk ${ }^{4}$ \\ ${ }^{1}$ Department of Obstetrics and Gynecology, Kafkas University Faculty of Medicine, Kars; ${ }^{2}$ Department of Medical Pathology, Çanakkale \\ Onsekiz Mart University Faculty of Medicine, Çanakkale; ${ }^{3}$ Department of Anatomy, Kafkas University Faculty of Medicine, Kars; \\ ${ }^{4}$ Department of Anesthesiology and Reanimation, Çanakkale Onsekiz Mart University Faculty of Medicine, Çanakkale, Turkey
}

\begin{abstract}
Aim: Although the etiology and physiopathology are not yet known, the possible effects of tubal sterilization (TS) on ovarian function are still debated. Limited studies analyzed the histopathology of endometrium and ovaries after TS. In this study, we aimed to evaluate the histopathological and biochemical changes of tubal sterilizations with the Pomeroy technique on tubal, ovarian, and endometrial tissues in rats.
\end{abstract}

Material and Method: Twenty female Wistar albino rats were randomly divided into two groups, with laparotomy only (Group 1) and laparotomy + TS (Group 2). Histopathological evaluation was performed after Hematoxylin-Eosin staining. Follicle-stimulating hormone (FSH), estradiol (E2), and lactate dehydrogenase (LDH) levels were biochemically measured.

Results: In Group 2, there was inflammation, hyalinization and congestion in the ovaries, tubas and endometrial tissues compared to Group 1. A statistically significant decrease in E2 ( $p<0.05)$ values was detected in Group 2 compared to Group 1. In Group 2, mean FSH and LDH ( $p>0.05$ ) values were found to be increased, although not statistically significant, compared to Group 1.

Conclusion: We can say that tubal sterilization causes detrimental effects such as inflammatory cell infiltration in the ovaries of rats. Further studies are needed to explain the possible mechanisms for the reduced ovarian reserves after tubal sterilization.

Key words: tubal sterilization; Pomeroy technique; ovary; endometrium; rat

\section{ÖZET}

Amaç: Tubal sterilizasyonunun (TS) overyan fonksiyonları üzerindeki olası etkileri, etiyolojisi ve fizyopatolojisi henüz bilinmemekle birlikte hala tartıșmalıdır. TS sonrası overyan ve endometriyal histopatoloji sınırlı çalıșmalarda analiz edildi. Bu çalıșmada, ratlarda Pomeroy tekniği ile tubal sterilizasyonun tubalar, overyan ve endometrial dokulardaki histopatolojik ve biyokimyasal değișimlerinin değerlendirmesi amaçlandı.
Materyal ve Metot: Yirmi adet diși Wistar albino rat, laparotomi (Grup 1) ve laparotomi + TS (Grup 2) olarak rastgele belirlenerek iki gruba ayrıldı. Hematoksilen-Eosin boyamasından sonra histopatolojik değerlendirme yapıldı. Folikül uyarıcı hormon (FSH), estradiol (E2) ve laktat dehidrojenaz $(\mathrm{LDH})$ seviyeleri biyokimyasal olarak ölçüldü.

Bulgular: Grup 2'de Grup 1'e göre overler, tubalar ve endometriyal dokularda inflamasyon, hyalinizasyon ve konjesyon vardı. Grup 2'de Grup 1'e göre E2 ( $p<0.05)$ değerlerindeki istatistiksel anlamlı düșüș tespit edildi. Grup 2'de Grup 1'e göre ortalama FSH ve LDH ( $p>0.05)$ değerlerinde ise istatistiksel olarak anlamlı olmasa da artıș tespit edildi.

Sonuç: Tubal sterilizasyonunun rat overlerinde enflamatuar hücre infiltrasyonu gibi zararlı etkilere neden olduğu söylenebilir. Tubal sterilizasyondan sonra azalan yumurtalık rezervlerinin muhtemel mekanizmalarını açıklamak için daha ileri çalıșmalara ihtiyaç vardır. Anahtar kelimeler: tubal sterilizasyon; Pomeroy tekniği; over; endometriyum; rat

\section{Introduction}

The most essential factor affecting rapid population growth in developing countries is childbirth. Augmented childbirth, in turn, triggers high-risk pregnancies. On the other hand, frequent risky pregnancies are the most significant factors that negatively affect mother and child health ${ }^{1,2}$. The most commonly preferred and performed method for family planning is tubal sterilization (TS). Technological advances have made TS in the long term a more reliable, effective, and cost-effective way ${ }^{3-5}$. However, short- and longterm risks of tubal sterilization have been reported in

IIetișim/Contact: Rulin Deniz, Kafkas Üniversitesi Tıp Fakültesi Kadın Hastalıkları ve Doğum Anabilim Dalı, Kars, Türkiye • Tel: 05335502846 • E-mail: rulindeniz@hotmail.com • Geliș/Received: 09.12.2019 • Kabul/Accepted: 16.12.2019

ORCID: Rulin Deniz, 0000-0002-7306-8212 • Yakup Baykus, 0000-0001-5730-8477 • Yasemen Adal, 0000-0002-8004-7364 • Muhammet Bora Uzuner, 0000-0001-6557-3086 • Ömür Öztürk, 0000-0003-2270-2778 
the current literature. It may cause post-TS problems, such as menstrual irregularities, chronic pelvic pain, dysmenorrhea, increased risk of osteoporosis, intrauterine and ectopic pregnancy (16-80\%), changes in sexual behavior, low pre-ovulatory estradiol (E2) or progesterone levels, and increased incidence of cumulative hysterectomy in the late period ${ }^{6-8}$.

Although the etiology and physiopathology are not yet known, the possible effects of TS on ovarian functions are still debated. There are limited studies analyzing the histopathology of endometrium and ovary after TS and showing its effects on these tissues ${ }^{6}$. Of those, some reported no significant change in ovarian reserves ${ }^{9,10}$ while others demonstrated definite findings of disturbances of ovarian functions ${ }^{11,12}$.

On the other hand, follicle stimulating hormone (FSH) and estradiol (E2) are the crucial hormones for women's pubertal development, female sex characteristics, and ovarian tissues ${ }^{13}$. Additionally, lactate dehydrogenase $(\mathrm{LDH})$ is an enzyme that indicates cytotoxicity and organizes some cellular pathways such as cellular proliferation, differentiation, angiogenesis, and apoptosis ${ }^{14}$. In this study, we aimed to evaluate the histopathological and biochemical changes of tubal sterilizations with the Pomeroy technique on the tubal, ovarian, and endometrial tissues in rats.

\section{Material and Method}

\section{Ethical Statement}

The animals were purchased from Ataturk University Medical Experimental Research and Application Center (ATADEM), and the study was approved by the Local Ethics Committee of Animal Experiments at Kafkas University (Approval date and number: 19.11.2015, KAU-HADYEK/2015-110). All animal procedures were performed following the "Guide for the Care and Use of Laboratory Animals" principles $^{15}$. Study reporting was done per the CONSORT principles $^{16}$.

\section{Animals and Study Procedures}

Twenty female Wistar albino rats (Rattus norvegicus), weighing 200-240 g, were used in this study as models for examining tubal sterilization. The rats were housed in an animal room maintained at a temperature of $25^{\circ} \mathrm{C}$ with alternating light periods ( 12 hours light/ 12 hours dark). Using random numbers, the rats were randomly allocated into two equal groups ( $n=10$ per group). The

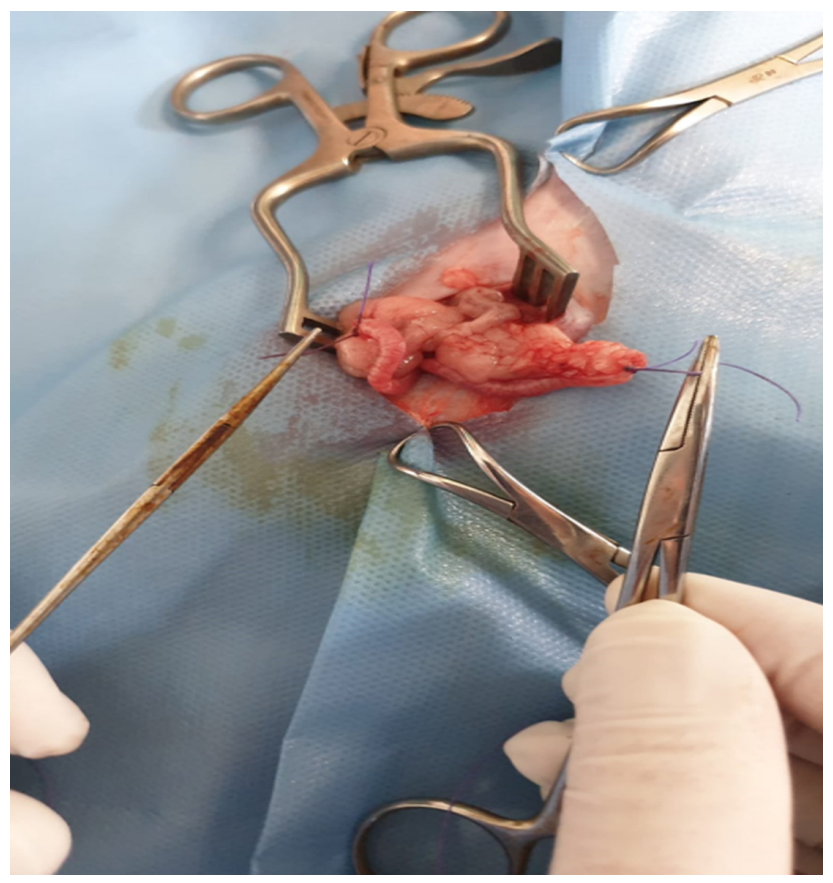

Figure 1. Tubal sterilization with the Pomeroy Technique.

first underwent only laparotomy (Group 1 - Control group), while the second group received laparotomy + Pomeroy tubal sterilization (Group 2 - Experimental group).

Animals were anesthetized intramuscularly using 50 $\mathrm{mg} / \mathrm{kg}$ of ketamine HCI. Before the experiment, the abdomens were shaved and disinfected with a $10 \%$ povidone-iodine solution. The ovaries and the uterine horns were exposed after a 3-cm midline incision. The rats in Group 1 did not undergo any surgical procedure except laparotomy. On the other hand, Group 2 received tubal sterilization with the Pomeroy technique. Each tube was ligated $1 \mathrm{~cm}$ away from the uterine horns with a $2 / 0$ catgut (Figure 1 ). Midline incisions were then sutured, and all rats were allowed to recover for 30 days. Thirty-day after the sterilization procedure, all rats underwent a laparotomy at the same incision site, when ovarian and endometrial tissues were removed bilaterally.

\section{Histopathological Analysis}

For histopathological analyses; ovaries, tuba, and the endometrium were fixed in $10 \%$ buffered neutral formalin for $72 \mathrm{~h}$, dehydrated in graded alcohol, cleared in xylene, and embedded in paraffin wax. Of the paraffin 
blocks, five-micrometer thick sections were obtained and stained with hematoxylin \& eosin. The stained sections were examined under light microscopy for histopathological evaluation. A pathologist blinded to the groups performed the histopathological analyses of tubal, endometrial, and ovarian changes.

\section{Biochemical Analysis}

Blood samples were taken from all experimental animals. They were centrifuged at $1000 \mathrm{G}$ and $2-8^{\circ} \mathrm{C}$ for 15 minutes, and the collected sera were transferred to sterile Eppendorf tubes. The sera were kept at $-80^{\circ} \mathrm{C}$ in a deep freeze until the day of analysis. Concentrations of E2 (ng/mL), FSH (ng/mL), and LDH (IU/L) were measured by an Enzyme-Linked Immunosorbent Assay (ELISA) method using commercially available Rat E2 ELISA kit, Rat FSH ELISA kit, and Rat LDH ELISA kit (Elabscience Biotechnology Inc., Houston, USA). All samples were run duplicate in the ELISA assay.

\section{Statistical Analysis}

Statistical analyses were performed with the help of the Statistical Package for Social Sciences version 22 (SPSS, IBM, Armonk, NY, USA). The independent samples t-test or Mann-Whitney $U$ test were used to compare two independent groups. The results were evaluated with a confidence interval of $95 \%$, and the level of significance, $p$, was set at 0.05 .

\section{Results}

\section{Histopathological Findings}

The histopathological results for ovarian, endometrial, and tubal tissues are seen in Figure 2, 3, and 4. When the histopathological changes in tubal tissues were evaluated, all tubal tissues in Group 1 were assessed as normal (Figure 2A), while dilatations were detected in all tissues of Group 2. Additionally, peritubal active chronic inflammation (Figure 2B), fibrosis (Figure $2 \mathrm{~B}$ ), hyalinization (Figure 2C), and pigment-containing intratubal lesions (Figure $2 \mathrm{C}$ ) were accompanying the dilatations in some of the tubal tissues in Group 2. On the other hand, similar findings were detected for the ovarian tissues in Group 1 and 2.

When the ovarian tissues were evaluated, it was seen that ovarian tissues in Group 1 were not entirely normal. It was possible to detect congestions in veins in the control group (Figure 3A). Additionally, Para ovarian cysts (Figure 3B) were accompanying the congestion and hemorrhage in the ovarian tissues of Group 2 rats.

On the other hand, the endometrial tissues of Group 1 were in their normal morphological limits (Figure $4 \mathrm{~A})$; however, a mild inflammation was detected in some of endometrial tissues of control group. Thinned endometrium (Figure 4B), the presence of endometrial stromal active inflammatory cells (Figure 4C), and endometrial stromal hyalinization (Figure 4D) were detected in the examination of the endometrial tissues in Group 2.

\section{Biochemical Findings}

When the biochemical findings were compared between the two groups, an increase in the mean values of FSH $(70.20 \pm 14.49$ vs. $(96.15 \pm 65.34)$ and LDH (850.22 \pm 135.74 vs. $887.66 \pm 119.55)$, and a decrease in the mean values of E2 $(146.40 \pm 16.91$ vs. (119.73 \pm 13.68$)$ were detected in Group 2 compared to Group 1. Mean values of the biochemical variables are given in Table 1 . There were no statistically differences between Group 1 and Group 2 regarding FSH and $\mathrm{LDH}$ levels $(\mathrm{Z}=-0.900, \mathrm{p}=0.368$ and $\mathrm{Z}=-0.530$ $p=0.596$, respectively). However, a statistically significant difference was detected between the two groups concerning E2 $(\mathrm{Z}=-2.870, \mathrm{p}=0.004)$.

\section{Discussion}

The Pomeroy technique for tubal sterilization is a widely preferred surgical female sterilization. It is a relatively easy, safe, and quite effective method for sterilization. The immediate symptoms of procedure are hemorrhage and infection. However, these are generally related the equipments and the skill of the surgeon ${ }^{17}$. Despite its popularity and ease of use, different reports are available in the literature about its long-term problems ${ }^{18,19}$. It was thought to result in the disturbance of the ovarian vascularity and change in hormone levels including FSH, LH, and E2 ${ }^{11}$.

According to the reports, the main method used to show ovarian functions are hormonal tests including serum FSH and E2 ${ }^{4}$. In our study, the experimental group subjected to TS with the Pomeroy technique showed elevation in FSH and reduction in E2 levels when compared to the control group. However, the increase in FSH levels was not statistically significant ( $p>0.05)$, while there was a substantial decrease in the E2 levels $(p<0.05)$. Kelekci et al. performed three different studies about the effects of tubal sterilization on 


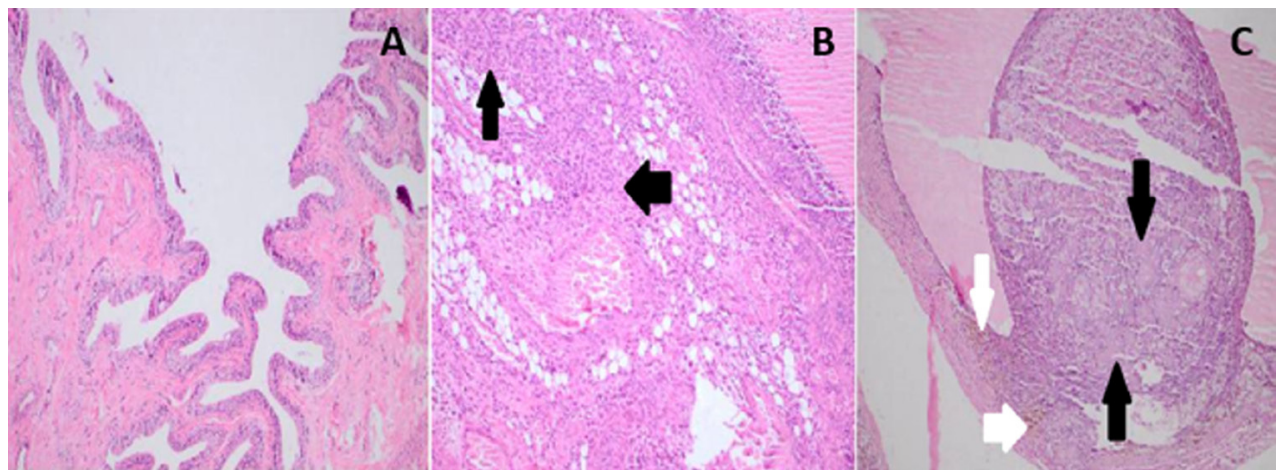

Figure 2. Tubal sections stained with hematoxylin \& eosin. A: Normal uterine tube (x100), B: Peritubal active chronic inflammation and fibrosis in Group 2 (x100), and C: hyalinization (black arrows) and pigment-containing intratubal lesion (white arrows) in Group 2 (x100).

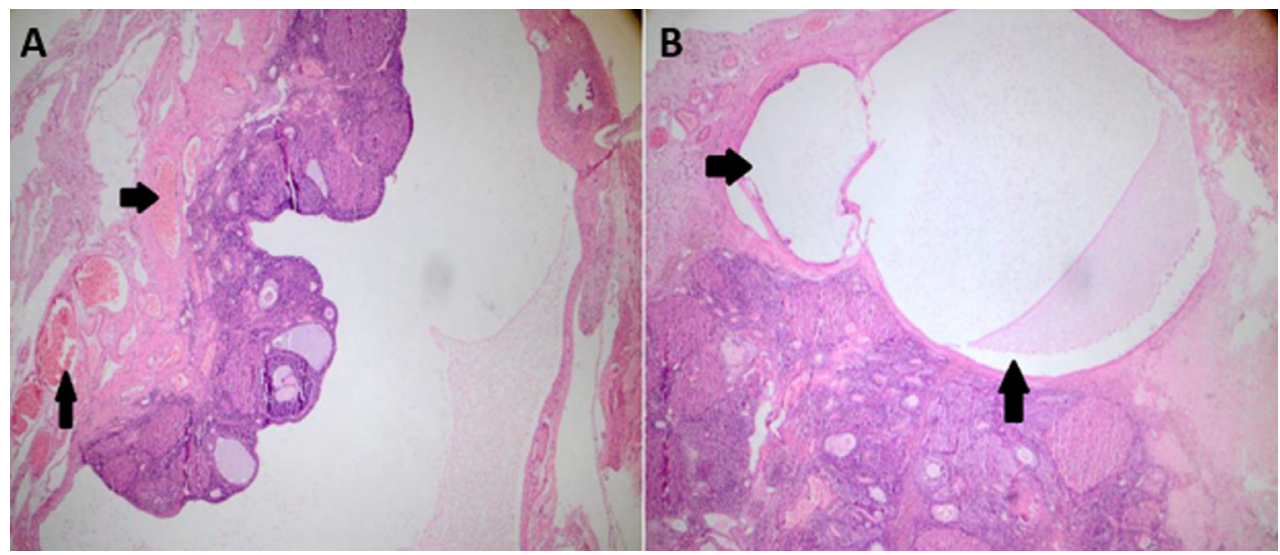

Figure 3. Ovarian sections stained with hematoxylene eosin. A: Congestion in veins of control group (x40), and B: Paraovarian cysts in Group 2 (x40).

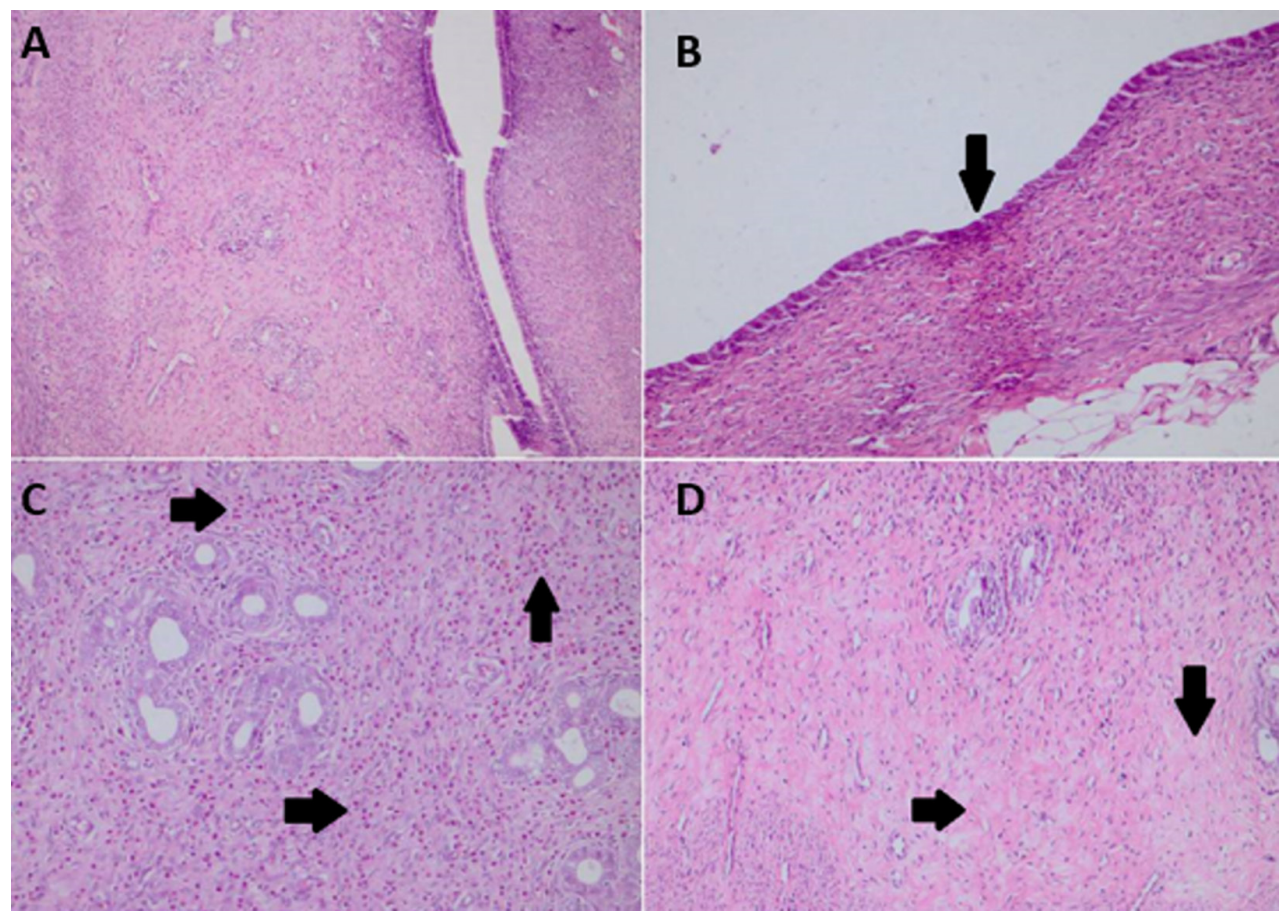

Figure 4. Endometrial sections stained with hematoxylin \& eosin. A: Normal endometrium (x100), B: Thinned endometrium in Group 2 (x200), C: Presence of endometrial stromal active inflammatory cells in Group 2 (x200), and D: Endometrial stromal hyalinization in Group 2 (x200). 


\begin{tabular}{lccc}
\hline & FSH $(\mathrm{ng} / \mathrm{mL})$ & E2 $(\mathrm{ng} / \mathrm{mL})$ & LDH (U/L) \\
\hline Groups & Mean \pm SD & Mean \pm SD & Mean \pm SD \\
Group 1 (Laparotomy) & $70.20 \pm 14.49$ & $146.40 \pm 16.91$ & $850.22 \pm 135.74$ \\
Group 2 (Laparotomy+TS) & $96.15 \pm 65.34$ & $119.73 \pm 13.68$ & $887.66 \pm 119.55$ \\
p Values & 0,368 & 0.004 & 0.596
\end{tabular}

hormonal and ovarian stromal blood supply changes ${ }^{4,5,20}$. They measured ovarian volume, number of antral follicles, intraovarian artery Doppler or hormone levels, and reported in both three studies that FSH levels were increased and E2 levels were decreased in the TS group compared to the controls. There was a significant increase in FSH but essential change in the E2 levels. Another study performed in Turkey ${ }^{11}$ confirmed these findings (increased FSH, and decreased E2 levels); however, the authors also reported that these hormonal changes were not statistically significant. On the other hand, Carmona et al. ${ }^{21}$ performed a similar study and reported that an increase was detected in both FSH and E2 levels. These changes were not significant too. Contradictory findings reporting increased $\mathrm{FSH}^{22}$, unchanged $\mathrm{FSH}^{23}$, increased $\mathrm{E}^{22}$, decreased E2 ${ }^{1}$, and unchanged E2 ${ }^{10}$ are available in medical literature.

On the other hand, ovarian functions of women after TS have been assessed by means of hormonal assays including FSH, LH, and E2. However, there have been limited studies about its histopathological effects on the endometrium and ovaries ${ }^{24,25}$. Additionally, most of the related studies performed a Doppler assessment of the blood stream samples of ovarian and uterine $\operatorname{arteries}^{6,7,11}$. In the present study, we assessed ovarian functions histopathologically using ovarian, endometrial, and tubal tissues, as well as hormonal assays. Compared to the control group, dilatation and inflammation in tubal tissues, congestion and hemorrhage in ovarian tissues, and hyalinization and inflammation in endometrial tissues were detected in the TS group. The number of histopathological reports in literature is limited and conflicting. Most studies have reported no correlation between tubal sterilization and ovarian histology $y^{25,26}$. However, others indicated pathologically a significant difference between the endometrium of the rats in the two groups. Also, Duran et al. ${ }^{25}$ reported that inflammatory cell infiltration of the sterilized rats was significantly higher than the control group. Endometrial inflammation may be the reason of menstrual irregularities. On the other hand, Souza et al. ${ }^{27}$ reported a reduced follicle reserve and follicle number 1-year after TS.

\section{Conclusion}

Limited rat studies in the literature about the effects of TS have stated that the rat model may not be suitable for testing the effects of sterilization on human ovarian and endometrial functions because of the differences that exists between two species regarding reproductive physiology. However, we can say that tubal sterilization causes detrimental effects such as inflammatory cell infiltration in the ovarian functions of rats. This may explain the menstrual problems occurring in the early period after TS. Further studies are needed to explain the possible mechanisms for reduced ovarian reserve.

\section{Study Limitations}

Our study has some limitations. First, TS with the Pomeroy technique could have been compared not only to laparotomy group but also to other family planning techniques. Second, luteinizing hormone (LH) should be measured to show the exact effects of TS on rat ovarian tissues. Third, hormone levels could have been measured both before and after the TS procedure. Forth, Doppler flowmetry should have been performed to assess any change in uterine or ovarial arterial flows. And finally, it should have been allowed at least 3 months (normally 6 or 12 months) to pass after the TS procedure to observe the long-term effects of TS on ovarian tissues. 


\section{References}

1. Rojansky N, Halbreich U. Prevalence and severity of premenstrual changes after tubal sterilization. J Reprod Med 1991;36(8):551-5.

2. Wilcox LS, Martinez-Schnell B, Peterson HB, Ware JH, Hughes JM. Menstrual function after tubal sterilization. Am J Epidemiol 1992;135(12):1368-81.

3. Huber AW, Mueller MD, Ghezzi F, Cromi A, Dreher E, Raio L. Tubal sterilization: complications of laparoscopy and minilaparotomy. Eur J Obstet Gynecol Reprod Biol 2007;134(1):105-9.

4. Kelekci S, Yilmaz B, Yakut Y, Yasar L, Savan K, Sonmez S. Hormonal and ovarian stromal blood supply changes after laparoscopic tubal sterilization: a prospective controlled study. Contraception 2006;73(3):279-83.

5. Kelekci S, Yorgancioglu Z, Yilmaz B, Yasar L, Savan K, Sonmez $S$, et al. Effect of tubal ligation on ovarian reserve and the ovarian stromal blood supply. Aust N Z J Obstet Gynaecol 2004; 44(5):449-51.

6. Aygen EM, Ozdamar S, Serin S, Babug M. Ovarian morphology of rats after fallopian tube sterilization. Contraception 2002;66(3):211-4.

7. Cevrioglu AS, Degirmenci B, Acar M, Yilmazer M, Erol D, Kahraman A, et al. Examination of changes caused by tubal sterilization in ovarian hormone secretion and uterine and ovarian artery blood flow rates. Contraception 2004;70(6):46773.

8. Kaya C, Turgut H, Cengiz H, Turan A, Ekin M, Yasar L. The effect of tubal sterilization with the Pomeroy technique and bipolar electrocauterization on the ovarian reserve and serum anti-Mullerian hormone levels in a rat model. Eur J Obstet Gynecol Reprod Biol 2015;185:108-13.

9. Kjer JJ, Mogensen AM. The arterial blood supply of the parametrium. Eur J Obstet Gynecol Reprod Biol 1989;30(3):275-8.

10. Wu E, Xiao B, Yan W, Li H, Wu B. Hormonal profile of the menstrual cycle in Chinese women after tubal sterilization. Contraception 1992;45(6):583-93.

11. Bulent Tiras M, Noyan V, Ozdemir H, Guner H, Yildiz A, Yildirim M. The changes in ovarian hormone levels and ovarian artery blood flow rate after laparoscopic tubal sterilization. Eur J Obstet Gynecol Reprod Biol 2001;99(2):219-21.

12. Kuscu E, Duran HE, Zeyneloglu HB, Demirhan B, Bagis T, Saygili E. The effect of surgical sterilization on ovarian function: a rat model. Eur J Obstet Gynecol Reprod Biol 2002;100(2):204-7.

13. Chen Y, Jefferson WN, Newbold RR, Padilla-Banks E, Pepling ME. Estradiol, progesterone, and genistein inhibit oocyte nest breakdown and primordial follicle assembly in the neonatal mouse ovary in vitro and in vivo. Endocrinology 2007;148(8):3580-90.
14. Simaga S, Osmak M, Babic D, Sprem M, Vukelic B, Abramic M. Quantitative biochemical analysis of lactate dehydrogenase in human ovarian tissues: correlation with tumor grade. Int J Gynecol Cancer 2005;15(3):438-44.

15. Committee for the Update of the Guide for the Care and Use of Laboratory Animals. Guide for the Care and Use of Laboratory Animals 2011.

16. Moher D, Schulz KF, Altman D, Group C. The CONSORT Statement: revised recommendations for improving the quality of reports of parallel-group randomized trials 2001. Explore (NY) 2005;1(1):40-5.

17. Taner CE, Aban M, Yilmaz N, Senturk N, Toy E. Pomeroy tubal ligation by laparoscopy and minilaparotomy. Adv Contracept 1994;10(2):151-5.

18. Krissi H, Orvieto R, Dicker D, Dekel A, Ben Rafael Z. Torsion of a fallopian tube following Pomeroy tubal ligation: a rare case report and review of the literature. Eur J Obstet Gynecol Reprod Biol 1997;72(1):107-9.

19. Revel A, Abramov Y, Yagel S, Nadjari M. Utero-ovarian morphology and blood flow after tubal ligation by the Pomeroy technique. Contraception 2004;69(2):151-6.

20. Kelekci S, Yilmaz B, Yasar L, Savan K, Sonmez S, Kart C. Ovarian reserve and ovarian stromal blood supply after tubal ligation by the Pomeroy technique: comparison with controls. Gynecol Endocrinol 2005;20(5):279-83.

21. Carmona F, Cristobal P, Casamitjana R, Balasch J. Effect of tubal sterilization on ovarian follicular reserve and function. Am J Obstet Gynecol 2003;189(2):447-52.

22. Hakverdi AU, Taner CE, Erden AC, Satici O. Changes in ovarian function after tubal sterilization. Adv Contracept 1994;10(1):51-6.

23. Alvarez F, Faundes A, Brache V, Tejada AS, Segal S. Prospective study of the pituitary-ovarian function after tubal sterilization by the Pomeroy or Uchida techniques. Fertil Steril 1989;51(4):604-8.

24. de Cristofaro D, Zancanari C, Fiaccavento S, Pezzoli C. Endometrial pathological changes after Fallopian ring tubal ligation. Endoscopy 1982;14(4):139-40.

25. Duran B, Demirkoprulu N, Guvenal T, Arici S, Tuncer E, Cetin $\mathrm{M}$, et al. Histopathological changes in ovary and endometrium after tubal ligation: a rat model. Acta Obstet Gynecol Scand 2003;82(3):220-4.

26. Riedel $\mathrm{HH}$, Ahrens $\mathrm{H}$, Semm K. Late complications of sterilization according to method. J Reprod Med 1981;26(7):353-8.

27. Souza AZ, Fonseca AM, Izzo VM, Clauzet RM, Salvatore CA. Ovarian histology and function after total abdominal hysterectomy. Obstet Gynecol. 1986;68(6):847-9. 